\title{
The Association between Selected Dietary Minerals and Mastitis in Dairy Cows-A Review
}

\author{
Kacper Libera ${ }^{1}$, Kacper Konieczny ${ }^{2}{ }^{\circledR}$, Katarzyna Witkowska ${ }^{1}{ }^{\circledR}$, Katarzyna Żurek ${ }^{1}$, \\ Małgorzata Szumacher-Strabel ${ }^{3}$, Adam Cieslak ${ }^{3}{ }^{(D)}$ and Sebastian Smulski ${ }^{2, *}$ \\ 1 Department of Preclinical Sciences and Infection Diseases, Poznan University of Life Sciences, \\ Wołyńska 35, 60-637 Poznań, Poland; kacper.libera@up.poznan.pl (K.L.); witko.katarzyna3@gmail.com (K.W.); \\ kacha.zurek@gmail.com (K.Ż.) \\ 2 Department of Internal Diseases and Diagnostics, Poznan University of Life Sciences, Wołyńska 35, \\ 60-637 Poznań, Poland; kacper.konieczny@up.poznan.pl \\ 3 Department of Animal Nutrition, Poznan University of Life Sciences, Wołyńska 33, 60-637 Poznań, Poland; \\ malgorzata.szumacher@up.poznan.pl (M.S.-S.); adam.cieslak@up.poznan.pl (A.C.) \\ * Correspondence: sebastian.smulski@up.poznan.pl
}

check for

updates

Citation: Libera, K.; Konieczny, K.; Witkowska, K.; Żurek, K.; SzumacherStrabel, M.; Cieslak, A.; Smulski, S. The Association between Selected Dietary Minerals and Mastitis in Dairy Cows-A Review. Animals 2021, 11, 2330. https://doi.org/ $10.3390 /$ ani11082330

Academic Editor: Alfonso Zecconi

Received: 2 July 2021

Accepted: 4 August 2021

Published: 7 August 2021

Publisher's Note: MDPI stays neutral with regard to jurisdictional claims in published maps and institutional affiliations.

Copyright: (c) 2021 by the authors. Licensee MDPI, Basel, Switzerland. This article is an open access article distributed under the terms and conditions of the Creative Commons Attribution (CC BY) license (https:/ / creativecommons.org/licenses/by/ $4.0 /)$.
Simple Summary: Inflammation of the mammary gland (mastitis) is an important disease in dairy cows. Among factors affecting the incidence of mastitis, mineral deficiencies are mentioned, since they strongly influence the immune system. Consequently, these deficiencies result in weakened immunity, which increases the risk of any infectious disease. The reviewed minerals (calcium, phosphorus, magnesium, selenium, copper and zinc) interact differently with the immune system; nevertheless, their deficiencies invariably increase the risk of mastitis occurrence in dairy cows.

Abstract: The aim of this paper is to describe the association between selected dietary minerals and mastitis in dairy cows. Minerals are a group of nutrients with a proven effect on production and reproductive performance. They also strongly affect immune system function. In particular their deficiencies may result in immunosuppression, which is a predisposing factor for udder inflammation occurrence. The role of selected dietary minerals (including calcium, phosphorus, magnesium, selenium, copper and zinc) has been reviewed. Generally, minerals form structural parts of the body; as cofactors of various enzymes they are involved in nerve signaling, muscle contraction and proper keratosis. Their deficiencies lead to reduced activity of immune cells or malfunction of teat innate defense mechanisms, which in turn promote the development of mastitis. Special attention was also paid to minerals applied as nanoparticles, which in the future may turn out to be an effective tool against animal diseases, including mastitis. To conclude, minerals are an important group of nutrients, which should be taken into account on dairy farms when aiming to achieve high udder health status.

Keywords: mastitis; minerals; immunosuppression; dairy cows; dietary deficiencies

\section{Introduction}

Mastitis is considered one of the most costly diseases in dairy cows, causing severe losses in the dairy industry [1]. Losses do not only refer to economic issues including milk quality and quantity, antibiotic usage or extra labor; they also refer to the disease significantly affecting animal welfare and public health. The etiology of udder inflammation is mainly associated with bacteria, i.e., staphylococci and streptococci, although viruses, fungi and algae can also cause mastitis [2]. Moreover, non-infectious factors such as genotype, environmental conditions, feed composition and dietary supplement addition may also have an impact on mastitis occurrence and its severity [3]. It is well proven that even in the presence of bacteria the immune system can cope with microbial invasion and prevent the development of inflammation. Any nutrition deficiency will result in a 
weakened immune response and thus be a predisposing factor for udder inflammation. Minerals are a group of nutrients that has been reported to influence udder health status. Basically, they take part in the formation of structural components of the body and proper functioning of enzymes, hormones, vitamins and cells. By the mid- to late 19th century, it was already known that animals need to consume certain minerals to live and be productive, but their specific role and daily requirements were not recognized [4]. Minerals can be divided into two groups based on their concentration in the organism: macrominerals that are present in the animal body in relatively high concentrations, and trace minerals or microelements found in relatively small amounts in the organism. Macrominerals include calcium $(\mathrm{Ca})$, phosphorus $(\mathrm{P})$, sodium $(\mathrm{Na})$, chlorine $(\mathrm{Cl})$, sulfur $(\mathrm{S})$ and magnesium $(\mathrm{Mg})$, while microelements include iron $(\mathrm{Fe})$, copper $(\mathrm{Cu})$, manganese $(\mathrm{Mn})$, zinc $(\mathrm{Zn})$, cobalt $(\mathrm{Co})$, chromium $(\mathrm{Cr})$, iodine (I), molybdenum $(\mathrm{Mb})$ and selenium $(\mathrm{Se})$ [5].

Microelements occur in relatively small amounts in living organisms. Moreover, aluminum $(\mathrm{Al})$, arsenic $(\mathrm{As})$, nickel $(\mathrm{Ni})$, silicon $(\mathrm{Si})$, tin $(\mathrm{Sn})$ and vanadium $(\mathrm{V})$ are also considered trace minerals, but they are present in extremely low concentrations and their specific roles are not yet fully understood. The reference values of selected serum mineral concentrations in dairy cows are presented in Table 1 . The given values collected from selected publications indicate that the production, health and reproduction performance of studied cows was kept at the optimum level, since both deficiencies and excess of dietary minerals can have a detrimental effect on animals, the environment and dairy farm profitability.

Table 1. Reference values of serum mineral concentrations in dairy cows.

\begin{tabular}{ccc}
\hline Mineral & Serum Concentration & Reference \\
\hline Calcium $(\mathrm{Ca})$ & $2.2-2.6 \mathrm{mmol} / \mathrm{L}$ & {$[6]$} \\
Phosphorus $(\mathrm{P})$ & $1.3-2.6 \mathrm{mmol} / \mathrm{L}$ & {$[6]$} \\
Magnesium $(\mathrm{Mg})$ & $0.75-1.0 \mathrm{mmol} / \mathrm{L}$ & {$[7]$} \\
Selenium $(\mathrm{Se})$ & $0.73-1.08 \mu \mathrm{mol} / \mathrm{L}$ & {$[8]$} \\
Copper $(\mathrm{Cu})$ & $1-18 \mu \mathrm{mol} / \mathrm{L}$ & {$[9]$} \\
Zinc $(\mathrm{Zn})$ & $8-19 \mu \mathrm{mol} / \mathrm{L}$ & {$[10]$} \\
\hline
\end{tabular}

In cattle veterinary medicine, mineral deficiencies are mainly associated with characteristic metabolic disorders such as periparturient hypocalcemia (milk fever), hypophosphatemia and hypomagnesemia (grass staggers). However, it has to be remembered that every mineral deficiency leads to immunosuppression [4], which is a well-recognized predisposing factor for the occurrence of infectious diseases including mastitis. Obviously, the key factor determining the concentration of a specific mineral in the body is its supply via feed. Thus, dietary requirements for dairy cows depending of their physiological state are presented in Table 2.

Table 2. Daily dietary requirements for selected minerals in dairy cows taking into account their physiological state (lactating/non-lactating) according to the Nutrient Requirements of Dairy Cattle [5].

\begin{tabular}{cccc}
\hline Mineral & $\begin{array}{c}\text { Requirement for Non-Lactating } \\
\text { Cows }\end{array}$ & $\begin{array}{c}\text { Concentration in Milk } \\
\text { (mg/kg) }\end{array}$ & Requirement for Lactating Cows \\
\hline Calcium $(\mathrm{Ca})$ & $0.0154 \mathrm{~g} / \mathrm{kg} \mathrm{BW}$ & 1220 & $0.106 \mathrm{~g} / \mathrm{kg} \mathrm{BW}$ \\
Phosphorus $(\mathrm{P})$ & $1 \mathrm{~g} / \mathrm{kg} \mathrm{DMI}$ & 900 & $2.5 \mathrm{~g} / \mathrm{kg} \mathrm{DMI}$ \\
Magnesium $(\mathrm{Mg})$ & $3 \mathrm{mg} / \mathrm{kg} \mathrm{BW}$ & 150 & $10 \mathrm{mg} / \mathrm{kg} \mathrm{BW}$ \\
Copper $(\mathrm{Cu})$ & $152 \mathrm{mg} / \mathrm{cow}(15.2 \mathrm{mg} / \mathrm{kg} \mathrm{DMI})$ & 0.015 & $313 \mathrm{mg} / \mathrm{cow}(15.7 \mathrm{mg} / \mathrm{kg} \mathrm{DMI})$ \\
Selenium $(\mathrm{Se})$ & $0.3 \mathrm{mg} / \mathrm{kg} \mathrm{DMI}$ & $0.01-0.025$ & $0.3 \mathrm{mg} / \mathrm{kg} \mathrm{DMI}$ \\
Zinc $(\mathrm{Zn})$ & $310 \mathrm{mg} / \mathrm{day}(31 \mathrm{mg} / \mathrm{kg} \mathrm{DMI})$ & 4 & $1261 \mathrm{mg} / \mathrm{day}(63 \mathrm{mg} / \mathrm{kg} \mathrm{DMI})$ \\
\hline
\end{tabular}

Assumptions: $650 \mathrm{~kg}$ body weight (BW) Holstein cow, $40 \mathrm{~kg}$ of milk per day if lactating, dry matter intake (DMI) in lactating/non-lactating cow equals $20 / 10 \mathrm{~kg}$ per day. 
In dairy production, mineral supplementation is a well-proven practice to increase reproductive performance [11,12], but its effect on cow health status including mastitis has also been investigated $[13,14]$. However, to the best of our knowledge there are practically no papers reviewing in detail the association between minerals and bovine mastitis.

The following part of the text will present selected minerals and the contribution of their deficiencies to immune system dysfunction and consequently the occurrence of udder inflammation.

\section{Calcium}

Calcium (Ca) takes part in various functions in the organism; it forms the structural components of the body and is essential for muscle contraction both in skeletal and smooth muscles including the teat sphincter, in which efficient contraction after milking is crucial to prevent microbial invasion into the udder [15]. In terms of hypocalcemia, contraction of the teat sphincter is impaired [16] and leads to an increased risk of mastitis in Holstein cows. Ca is also considered a blood clotting agent, thus hypocalcemia may result in a reddish coloration of milk due to microhemorrhages in the mammary glands of cows of different dairy breeds [17]. This mineral is also involved in conduction of nerve signals. Cows are relatively susceptible to hypocalcemia due to great losses of this mineral in milk. The crucial period for calcium deficiency to occur is the time within $72 \mathrm{~h}$ after parturition. In that period, cows promptly start to produce large amounts of milk and thus excrete considerable amounts of $\mathrm{Ca}$, which may lead to its deficiency [17]. The clinical form of hypocalcemia, known as milk fever or parturient paresis, is a metabolic disorder characterized by lowered serum calcium concentration, usually below $1.5 \mathrm{mmol} / \mathrm{L}$, and specific clinical signs, including prolonged sternal recumbency, loss of appetite, muscle weakness, tachycardia and hypothermia [17]. In extreme cases coma can occur and circulatory collapse may lead to death.

Kimura et al. [18] stated that in Jersey cows before parturition Ca concentration decreases in peripheral blood mononuclear cells leading to the development of hypocalcemia, which contributes to immunosuppression, because calcium is crucial for activating immune system cells [19], in particular neutrophils [20]. It is consistent with the results of studies conducted by Ducusin et al. [21] and Martinez et al. [22], who observed decreased phagocytic activity of neutrophils derived from hypocalcaemic Holstein cows compared to normocalcaemic cows. Those authors indicated subclinical hypocalcemia as a factor predisposing to infections. In a study conducted on Holstein cows by Hisaeda et al. [23], the blood calcium concentration was significantly lower in cows with peracute coliform mastitis compared to healthy cows. Those authors suggested that this phenomenon occurred because of the production of inflammatory cytokines in mastitic cows, which decreases PTH secretion and the conversion of $25-\mathrm{OH}$ vitamin $\mathrm{D}$ to $1.25-\mathrm{D}$ and consequently results in a reduced calcium concentration. Meglia et al. [24] found a decrease in concentrations of several minerals, including calcium, in the period around calving in Swedish dairy cows, which was associated with a lower proportion of neutrophils expressing adhesive molecules (CD62L). However, Rodriguez et al. [25] as well as Chamberlin et al. [26] found no statistically significant differences in somatic cell counts between Holstein cows with hypocalcemia and cows with appropriate Ca concentrations.

\section{Phosphorus}

Phosphorus (P), of which $85 \%$ is present in the skeletal system, is an essential component of nucleic acids (DNA and RNA) and is contained in high-energy compounds such as ATP [27]. This mineral is also involved in buffering the $\mathrm{pH}$ (phosphate buffer) of body fluids. Phosphorus deficiency, especially around calving and in early lactation, has been associated with hampered productivity, feed intake depression and an increased risk of morbidity in fresh cows [27]. When investigating the immune system and resistance to infection, Eisenberg et al. [28] stated that hypophosphatemia negatively affects both phagocytic activity and granulocyte count in transition Holstein dairy cows. However, 
in research conducted earlier by the same authors [29], granulocytes derived from cows fed a phosphorus-deficient diet were less viable, but phagocytic activity was not affected. Mullarky et al. [30] observed no effect of different P dietary supply levels on the phagocytic activity of granulocytes or lymphocyte proliferation. The mechanism associated with impaired activity of immune cells in cows with phosphorus deficiency has not been fully investigated. Reports on other animal species such as rats suggest that ATP content of leukocytes tends to be lower in hypophosphatemic individuals and that explains their decreased phagocytic activity and proliferation [31]. It is important to note that there are concerns regarding environmental pollution with $\mathrm{P}$ of fecal origin, thus it has been suggested that the $\mathrm{P}$ content of manure should be limited, thereby enforcing a more restrictive use of $\mathrm{P}$ in bovine nutrition [28].

\section{Magnesium}

Magnesium (Mg) plays an essential role in cell metabolism and acts as a cofactor for over 300 enzymes including alkaline phosphatase, phosphomonoesterase, pyrophosphatase and glycolytic enzymes such as hexokinase, phosphoglucomutase, phosphofructokinase, phosphoglycerate kinase, phosphoglycerate mutase and enzymes involved in the citric acid cycle (tricarboxylic acid cycle; Krebs cycle) such as the pyruvate dehydrogenase complex or isocitrate dehydrogenase [32]. In addition, an appropriate intracellular magnesium concentration is required for $\mathrm{Na}^{+} / \mathrm{K}^{+}$-ATPase functioning [32]. The primary site of $\mathrm{Mg} 2+$ absorption is the rumen and it may be influenced by diet type and forage type [33]. Referring to the immune system, $\mathrm{Mg}$ is an integral part of the innate immune response, id est, the complement system as well as properdin. Generally, to the best of our knowledge, there are no papers regarding magnesium and its role in the bovine immune system; however, many studies have been carried out on rodents. For example, Weglicki et al. [34] observed increased levels of proinflammatory cytokines (IL-6, TNF- $\alpha$ ) in rats under $\mathrm{Mg}$ deprivation for three weeks. This is in agreement with the findings reported by Malpuech-Brugère et al. [35], who also noticed an increased IL-6 concentration in Mg-depleted rats. Furthermore, Van Orden et al. [36] recorded increased total leukocyte counts in rats fed a diet that was extremely low in $\mathrm{Mg}$ compared to the control group (30 ppm). This corresponds with the results of a study performed by Bussiere et al. [37], who noticed an elevated level of IL- 6 and an increased count of polymorphonuclear cells in $\mathrm{Mg}$-deficient rats compared to rats in the control. The authors claim that an enhanced inflammatory response is a consequence of $\mathrm{Mg}$ deficiency and that the reduced extracellular $\mathrm{Mg}$ level might be responsible for the activated state of immune cells. However, there are reports suggesting an association between $\mathrm{Mg}$ deficiency and increased prevalence of lameness in cattle [38], or claims that $\mathrm{Mg}$ has a promoting effect on both pre-implantation blastocysts and term development post-embryo-transfer in Holstein cattle [39]. Taking into account all these results, magnesium is an important factor for the immune system, but it is not clear if $\mathrm{Mg}$ deficiency itself acts as a proinflammatory factor or rather results in immunosuppression, which in turn promotes inflammation. Therefore, further studies of cattle are required to fully understand its role.

\section{Selenium}

Selenium (Se) is a semimetal, which is found in relatively small amounts in animal organisms. In dairy science it is well documented that selenium supplementation can enhance growth, reproductive performance and health status in cattle [40]. Selenium deficiencies may result in calf growth retardation, immunosuppression and difficulties in reproduction. It is involved in antioxidant defense, redox state regulation and a variety of specific metabolic pathways, but some biological functions of selenium are still unknown. It is also a constitutive part of the 21st amino acid named selenocysteine [40]. 
Referring to the immune system, Se is contained in the active center of the enzyme glutathione peroxidase (GSH-Px), which reduces reactive oxygen species and so has an antioxidant effect. Thus, selenium supplementation may result in positive clinical responses under various conditions with increased oxidative damage such as mastitis [8]. Moreover, studies report that selenium concentration may influence bovine neutrophil performance and their ability to neutralize microorganisms. Neutrophils are considered to be immunocytes, which play an important role during phagocytosis and act in the line of defense against microorganisms invading the mammary gland. In vitro studies based on bovine neutrophils showed that Se supplementation enhances chemotactic migration, phagocytosis and serum superoxide dismutase (SOD) activity [41], and intracellular antibacterial activity against $S$. aureus [42]. More recent studies have suggested [43] that selenium may play a crucial role in immune and inflammatory regulation by influencing the differential expression of exosomal mRNAs of key genes in bovine mastitis. They demonstrated that selenium affects mRNA expression in MAC-T-cell-derived exosomes related to immunity and inflammatory pathways. A study carried out by Wang et al. [44] showed that selenium down-regulates inflammatory mediators TNF- $\alpha$ and IL- $1 \beta$, and IL- 6 gene expression, which may be responsible for the anti-inflammatory effect of Se. In turn, Boyne et al. [45] found neutrophils that were less able to kill Candida albicans when they were derived from Se-deficient steers. The above-mentioned in vitro studies have been supported by many field trials. Researchers have reported the highest treatment efficiency when an antibiotic was combined with selenium preparation [46,47] and reported a lower incidence of clinical mastitis when Holstein cows were supplemented with this mineral [48], or a shorter duration of clinical symptoms [49]. The somatic cell count is negatively correlated with the serum selenium level [50]. Selenium significantly inhibits the expression of NLRP3, ASC, Caspase-1, Caspase-1 p20 and Pro-IL-1 $\beta$. Dietary selenium can attenuate Staphylococcus aureus mastitis by the inhibition of the NLRP3 inflammasome [43]. In addition, a beneficial effect on mastitis treatment was observed when affected cows were injected with a multimineral preparation containing Se [41,51]. In contrast, Ganda et al. [13] reported no beneficial effect on overall cure rate of subclinical mastitis when lactating cows were supplemented with a mix of trace minerals. Special attention should be paid to the chemical form of selenium, since for several years scientists have been working on new, less toxic forms of selenium supplementation. Żarczyńska et al. [52] indicated that selenite triglycerides are safe and effective selenium supplements for cattle. Moreover, organic sources of Se (Se yeast, Se-Met, and HMSeBA) are considered efficient bioavailable sources compared with inorganic Se. Nowadays, nano-Se is receiving more attention due to its multiple health benefits compared with inorganic and organic Se sources for use in dairy animals [53]. Gopi et al. [54] indicated that the comparative advantage and efficacy of nanoparticles stem from their smaller particle size and larger surface area, enhanced mucosal permeability, and higher intestinal absorption as a result of nanoemulsion formation. In addition to its enhanced bioavailability, nano-Se also exhibits reduced toxicity and lower antagonism with other minerals compared with other sources of Se. Wichtel et al. [55] stated that measuring selenium concentration in bulk tank milk could be a useful tool to assess herd selenium status. If the concentration is below $0.12 \mu \mathrm{mol} / \mathrm{L}$ of bulk tank milk, selenium deficiency is suspected, while selenium content over $0.28 \mu \mathrm{mol} / \mathrm{L}$ is adequate [55].

\section{Copper}

Copper $(\mathrm{Cu})$ is considered necessary for structural and catalytic properties of cuproenzymes (in Latin cuprum means copper) [56]. These include, inter alia, cytochrome-c oxidase, superoxide dismutase, catechol oxidase, ceruloplasmin and amine oxidases. It is the second most common metal, immediately after zinc, in various enzymes, for which $\mathrm{Cu}$ is essential for their appropriate function [57]. It is also involved in collagen and elastin synthesis as well as myelination and hemoglobin production [56].

Considering the immune system and mastitis microorganisms, copper is believed to exhibit antibacterial properties against bacteria isolated from mastitic cows. According to 
Reyes-Jara et al. [58], $\mathrm{Cu}$ concentration as low as $250 \mathrm{ppm}$ inhibits the growth of common mastitis microorganisms such as Escherichia coli and coagulase negative Staphylococci. This is consistent with the results reported both by Wernicki et al. [59] and Kalińska et al. [60], who stated that nanoparticles of silver and copper exhibit the highest antimicrobial activity against bacteria isolated from inflamed udders. This suggests that a copper preparation may be considered a reliable alternative to dipping solutions. Furthermore, in vivo studies reported that 100-day dietary $\mathrm{Cu}$ supplementation (Cu concentration in the experimental group at $20 \mathrm{ppm}$ vs $6.5 \mathrm{ppm}$ in the control) resulted in a reduced clinical response when Holstein cows were experimentally intramammary infected with E. coli [61]. This is supported by a study carried out by Gakhar et al. [62], who observed a reduced incidence of postpartum mastitis in cows supplemented with copper compared to the non-supplemented group. Copper deficiencies result in impaired phagocytosis and decreased $\mathrm{Cu}, \mathrm{Zn}-\mathrm{SOD}$ activity [63], whereas $\mathrm{Cu}$ antimicrobial properties are explained by the disruption of bacterial lipids, proteins and DNA through oxidation [64].

\section{Zinc}

Zinc $(\mathrm{Zn})$ is a microelement that plays a crucial role in rumen microbiota maintenance and synthesis of proteins including collagen, glucagon, insulin, as well as in DNA and RNA synthesis [65]. $\mathrm{Zn}$ is an essential activator for the highest number of enzymes including alkaline phosphatase, carbonic anhydrase, DNA and RNA polymerase and (together with $\mathrm{Cu}$ ) superoxide dismutase, which plays a key role in antioxidant processes [57]. $\mathrm{Zn}$ is also a cofactor for a series of oxidoreductases and takes part in keratin formation. In terms of the effect of $\mathrm{Zn}$ on health performance in dairy cattle, some studies reported that dietary supplementation of zinc decreased somatic cell count $[66,67]$ and milk amyloid A levels [66]. In contrast, Whitaker et al. [68] recorded no effect of dietary zinc supplementation on somatic cell count. Intact mammary epithelium impenetrable for microorganisms is considered an innate part of the udder immune system. Weng et al. [69] reported improved integrity of mammary epithelium when Holstein cows were supplemented with Zn preparations; however, conflicting results were obtained by Shaffer et al. [70]. Zinc is crucial for the development and proper function of cells mediating innate immunity such as neutrophils. Deficiency of this mineral adversely affects the growth and function of T and B cells. $\mathrm{Zn}$ exhibits antioxidant properties and stabilizes membranes, which suggest its role in the prevention of free-radical-induced injury during inflammatory processes [71].

\section{Mineral Nanoparticles-A Promising Tool in Udder Inflammation Management}

In animal production, minerals can be incorporated into the diet or used in therapy in different forms, including inorganic salts, organic forms, chelates or as nanoparticles. Many reports have shown evidence that nanoparticles may be good candidates for animal growth promoters, antimicrobials and promising future alternatives to conventional cleaning agents [72]. Nanoparticles (NPs) including nanometals and nanometal oxides are defined as nanosized structures with one or more of their dimensions (length, width or thickness) in the nanometer range of 1-100 nm [72]. The most important advantage of NPs is that they do not lead to bacterial resistance [73]. Using them as a new dipping solution is currently considered. NPs may have a toxic effect on bacteria because of the formation of reactive oxygen species (in the Fenton reaction), DNA degradation, and lipid and protein peroxidation [74]. In the literature, nanoparticles containing copper (CuNPs), silver (AgNPs), platinum (Pt_NPs) and zinc (ZnONPs) have been described [60]. For example, it has been reported that CuNPs demonstrate significant inhibitory activity against several bacteria species, e.g., Escherichia coli, Klebsiella pneumoniae, Pseudomonas aeruginosa, Propionibacterium acnes and Salmonella typhi. Moreover, CuNPs display an antifungal activity against the Candida species [75], which can cause mastitis. Furthermore, S. aureus strains isolated from clinical and subclinical cases of mastitis exhibit significant susceptibility to AgNPs and AuNPs [76]. In addition, ZnO-NPs also exhibit antimicrobial properties against S. aureus and other pathogenic bacteria such as E. coli and K. pneumoniae [77]. Previous 
studies showed that AgNPs can be used in diseases caused by algae [78] that are also involved in udder inflammation. According to Wernicki et al. [59], AgNPs and CuNPs may be the most effective solution in mastitis management due to their synergistic effect on various pathogens. An in vitro study revealed that the oxidoreductive activity of BME-UV1 cells increased after incubation in media containing 0.5 and $1 \mathrm{mg} / \mathrm{mL}$ of AgNPs and in media containing $0.1,0.5$ and $1 \mathrm{mg} / \mathrm{L}$ of AgCuNPs. However, higher concentrations of selected NPs decreased the oxidoreductive activity of BME-UV1 cells. Conversely, data on HMEC cell viability after incubation in media containing AgNPs, CuNPs or AgCuNPs at concentrations of $0.1,0.5,1,2$ and $2.5 \mathrm{mg} / \mathrm{L}$ showed no decrease in the oxidoreductive activity of HMEC cells and therefore they did not have any cytotoxic effect [60]. However, a question arises concerning the safety of NP administration. It is important to highlight that limited in vivo evidence is available to support many applications demonstrated in vitro [72]. The reports are not consistent. On the one hand, silver nanoparticles are reported to be cytotoxic and genotoxic for human microvascular endothelial cells [79]. On the other hand, histopathological examination of various organs from treated rats shows that AgNPs and AuNPs are not toxic at low doses [76]. Furthermore, the NPs analyzed in this study did not reveal a toxic effect on BME-UV1 or HMEC cells, but an elevated LDH level was observed after the incubation of NPs with BME-UV1 cells. Nevertheless, the dose and form of applied NPs seem to be key factors determining toxicity. Therefore, the addition of NPs should potentially be safe for cattle and humans, but further studies are required.

\section{Mineral Supplementation as an Auxiliary Tool in Mastitis Treatment-Field Trials}

From a clinical point of view, it is well-known that some mastitis cases require supportive therapy including fluids with calcium, since cows with udder inflammation are often hypocalcaemic [80]. Besides, the injectable supplementation of trace minerals, such as zinc, manganese, selenium and copper, can also be considered as an auxiliary tool in therapy of mastitis in dairy cows. For example, Hoque et al. [47] claimed that antimicrobial therapy is the most effective in mastitis treatment; however, in the same experiment cows injected only with selenium preparations were less prone to udder inflammation compared to the untreated control group. Ganda et al. [13] demonstrated that injection of trace minerals (including zinc, manganese, selenium and copper) reduces the number of chronic mastitis cases, but has no impact on the incidence of clinical cases requiring treatment. Machado et al. [14] showed that injection of a multimineral preparation (including selenium, copper, zinc and manganese) had a positive impact on udder health, decreasing linear somatic cell count (SCC) scores and the incidence of subclinical and clinical mastitis. Moreover, the same researchers reported that administration of this multimineral preparation increases serum superoxide dismutase (SOD) activity, but does not subsequently affect leukocyte function [41]. However, Ferreira and Petzer [81] observed no evident correlation between SCC and the milk or serum selenium values in cows supplemented with Se in different forms, while in a study performed by Bourne et al. [82], supplementation of vitamin $\mathrm{E}$ with Se reduced the risk of culling and mastitis rate by $10 \%$. Recently, Smulski et al. [83] confirmed that administration of an antibiotic combined with antioxidant including selenium slightly improves the effectiveness of clinical mastitis treatment.

To recap, a brief summary of the pathomechanisms related to mineral deficiencies and mastitis incidence is given in Figure 1. 


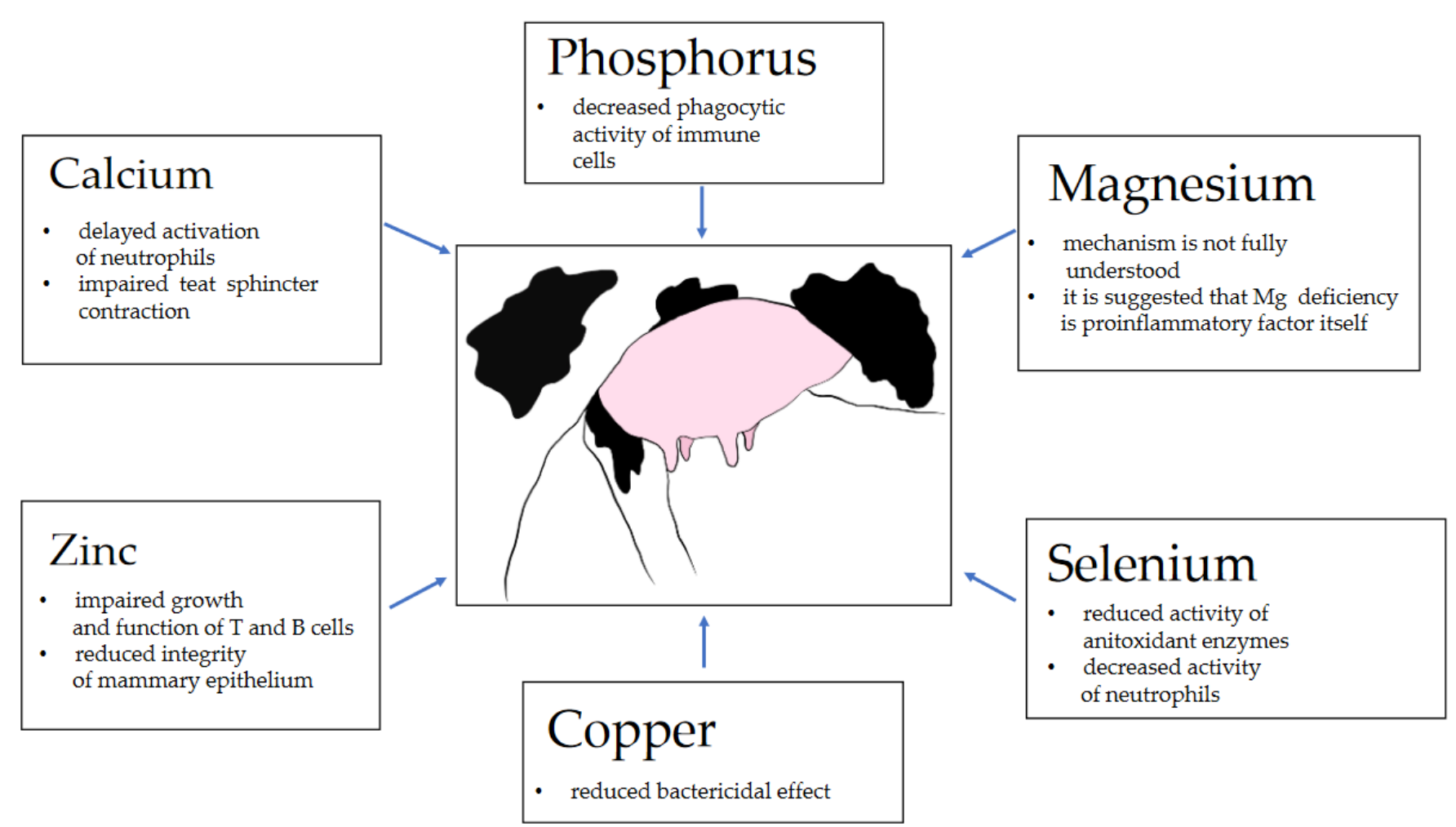

Figure 1. Brief summary of pathomechanisms related to mineral deficiencies and mastitis incidence.

\section{Conclusions}

When managing nutrition on a dairy farm, special attention should be paid to minerals because they are involved in various biological processes in cows and hence influence key traits in dairy production. Moreover, minerals are essential for the proper function of immune cells, so any mineral deficiency may lead to suppression of immunity, which predisposes cows to infection. Mastitis is an ongoing problem even on well-managed farms, and mineral supplementation might be a way to enhance the innate immunity of the mammary gland and thus contribute to a decreased risk of udder inflammation.

Author Contributions: Conceptualization, K.L., S.S. and M.S.-S.; formal analysis, K.L., S.S.; resources, K.L., K.K., K.Z. and K.W.; writing-original draft preparation.; K.L., K.K., K.W. and K.Ż.; writingreview and editing, K.L., M.S.-S., S.S. and A.C. All authors have read and agreed to the published version of the manuscript.

Funding: This research was supported within the framework of the Ministry of Science and Higher Education program "Regional Initiative Excellence" in the years 2019-2022 (Project No. 005/RID/2018/19) and by the Faculty of Veterinary Medicine and Animal Science, Poznan University of Life Sciences, Poland, from the Department of Internal Diseases and Diagnostics (no. 506.515.05.00).

Institutional Review Board Statement: Not applicable.

Informed Consent Statement: Not applicable.

Data Availability Statement: Not applicable.

Acknowledgments: We would like to thank Magdalena Raczkowska for helping us design Figure 1.

Conflicts of Interest: The authors declare no conflict of interest.

\section{References}

1. Romero, J.; Benavides, E.; Meza, C. Assessing Financial Impacts of Subclinical Mastitis on Colombian Dairy Farms. Front. Vet. Sci. 2018, 5, 273. [CrossRef] [PubMed]

2. Ruegg, P.L. A 100-Year Review: Mastitis Detection, Management, and Prevention. J. Dairy Sci. 2017, 100, 10381-10397. [CrossRef] [PubMed] 
3. Abebe, R.; Hatiya, H.; Abera, M.; Megersa, B.; Asmare, K. Bovine Mastitis: Prevalence, Risk Factors and Isolation of Staphylococcus Aureus in Dairy Herds at Hawassa Milk Shed, South Ethiopia. BMC Vet. Res. 2016, 12, 270. [CrossRef] [PubMed]

4. Weiss, W.P. A 100-Year Review: From Ascorbic Acid to Zinc-Mineral and Vitamin Nutrition of Dairy Cows. J. Dairy Sci. 2017, 100, 10045-10060. [CrossRef] [PubMed]

5. National Research Council. Nutrient Requirements of Dairy Cattle, 7th ed.; The National Academies Press: Washington, DC, USA, 2001.

6. Cozzi, G. Short Communication: Reference Values for Blood Parameters in Holstein Dairy Cows: Effects of Parity, Stage of Lactation, and Season of Production. J. Dairy Sci. 2011, 94, 7. [CrossRef] [PubMed]

7. Zelal, A. Hypomagnesemia Tetany in Cattle. J. Adv. Dairy Res. 2017, 5, 10. [CrossRef]

8. Mehdi, Y.; Dufrasne, I. Selenium in Cattle: A Review. Molecules 2016, 21, 545. [CrossRef]

9. Laven, R.; Lawrence, K.; Livesey, C. The Assessment of Blood Copper Status in Cattle: A Comparison of Measurements of Caeruloplasmin and Elemental Copper in Serum and Plasma. N. Z. Vet. J. 2007, 55, 171-176. [CrossRef]

10. Spolders, M.; Holtershinken, M.; Meyer, U.; Rehage, J.; Flachowsky, G. Assessment of Reference Values for Copper and Zinc in Blood Serum of First and Second Lactating Dairy Cows. Vet. Med. Int. 2010, 2010, 8. [CrossRef]

11. Chester-Jones, H.; Vermeire, D.; Brommelsiek, W.; Brokken, K.; Marx, G.; Linn, J.G. Effect of Trace Mineral Source on Reproduction and Milk Production in Holstein Cows. Prof. Anim. Sci. 2013, 29, 289-297. [CrossRef]

12. Molefe, K.; Mwanza, M. Effects of Mineral Supplementation on Reproductive Performance of Pregnant Cross-breed Bonsmara Cows: An Experimental Study. Reprod. Domest. Anim. 2020, 55, 301-308. [CrossRef] [PubMed]

13. Ganda, E.K.; Bisinotto, R.S.; Vasquez, A.K.; Teixeira, A.G.V.; Machado, V.S.; Foditsch, C.; Bicalho, M.; Lima, F.S.; Stephens, L.; Gomes, M.S.; et al. Effects of Injectable Trace Mineral Supplementation in Lactating Dairy Cows with Elevated Somatic Cell Counts. J. Dairy Sci. 2016, 99, 7319-7329. [CrossRef]

14. Machado, V.S.; Bicalho, M.L.S.; Pereira, R.V.; Caixeta, L.S.; Knauer, W.A.; Oikonomou, G.; Gilbert, R.O.; Bicalho, R.C. Effect of an Injectable Trace Mineral Supplement Containing Selenium, Copper, Zinc, and Manganese on the Health and Production of Lactating Holstein Cows. Vet. J. 2013, 197, 451-456. [CrossRef]

15. DeGaris, P.J.; Lean, I.J. Milk Fever in Dairy Cows: A Review of Pathophysiology and Control Principles. Vet. J. 2008, 176, 58-69. [CrossRef]

16. Goff, J.P. The Monitoring, Prevention, and Treatment of Milk Fever and Subclinical Hypocalcemia in Dairy Cows. Vet. J. 2008, 176, 50-57. [CrossRef]

17. Horst, R.L.; Goff, J.P.; McCluskey, B. Prevalence of Subclinical Hypocalcemia in U.S. Dairy Operations; US Department of Agriculture (USDA) Agricultural Research Service: Washington, DC, USA, 2003.

18. Kimura, K.; Reinhardt, T.A.; Goff, J.P. Parturition and Hypocalcemia Blunts Calcium Signals in Immune Cells of Dairy Cattle. J. Dairy Sci. 2006, 89, 2588-2595. [CrossRef]

19. Vig, M.; Kinet, J.-P. Calcium Signaling in Immune Cells. Nat. Immunol 2009, 10, 21-27. [CrossRef]

20. Zhang, B.; Guo, H.; Yang, W.; Li, M.; Zou, Y.; Loor, J.J.; Xia, C.; Xu, C. Effects of ORAI Calcium Release-Activated Calcium Modulator 1 (ORAI1) on Neutrophil Activity in Dairy Cows with Subclinical Hypocalcemia1. J. Anim. Sci. 2019, 97, 3326-3336. [CrossRef] [PubMed]

21. Ducusin, R.J.T.; Uzuka, Y.; Satoh, E.; Otani, M.; Nishimura, M.; Tanabe, S.; Sarashina, T. Effects of Extracellular Ca ${ }^{2+}$ on Phagocytosis and Intracellular $\mathrm{Ca}^{2+}$ Concentrations in Polymorphonuclear Leukocytes of Postpartum Dairy Cows. Res. Vet. Sci. 2003, 75, 27-32. [CrossRef]

22. Martinez, N.; Risco, C.A.; Lima, F.S.; Bisinotto, R.S.; Greco, L.F.; Ribeiro, E.S.; Maunsell, F.; Galvão, K.; Santos, J.E.P. Evaluation of Peripartal Calcium Status, Energetic Profile, and Neutrophil Function in Dairy Cows at Low or High Risk of Developing Uterine Disease. J. Dairy Sci. 2012, 95, 7158-7172. [CrossRef]

23. Hisaeda, K.; Koshiishi, T.; Sasaki, A.; Shinozuka, Y.; Isobe, N.; Kawai, K. Changes in Ionized Calcium Concentration in the Blood of Dairy Cows with Peracute Coliform Mastitis. J. Vet. Med. Sci. 2020, 82, 457-462. [CrossRef]

24. Meglia, G.E.; Johannisson, A.; Petersson, L.; Waller, K.P. Changes in Some Blood Micronutrients, Leukocytes and Neutrophil Expression of Adhesion Molecules in Periparturient Dairy Cows. Acta Vet. Scand. 2001, 42, 12. [CrossRef] [PubMed]

25. Rodríguez, E.M.; Arís, A.; Bach, A. Associations between Subclinical Hypocalcemia and Postparturient Diseases in Dairy Cows. J. Dairy Sci. 2017, 100, 7427-7434. [CrossRef] [PubMed]

26. Chamberlin, W.G.; Middleton, J.R.; Spain, J.N.; Johnson, G.C.; Ellersieck, M.R.; Pithua, P. Subclinical Hypocalcemia, Plasma Biochemical Parameters, Lipid Metabolism, Postpartum Disease, and Fertility in Postparturient Dairy Cows. J. Dairy Sci. 2013, 96, 7001-7013. [CrossRef]

27. Grünberg, W. Treatment of Phosphorus Balance Disorders. Vet. Clin. N. Am. Food Anim. Pract. 2014, 30, 383-408. [CrossRef]

28. Eisenberg, S.W.F.; Ravesloot, L.; Koets, A.P.; Grünberg, W. Effect of Dietary Phosphorus Deprivation on Leukocyte Function in Transition Cows. J. Dairy Sci. 2019, 102, 1559-1570. [CrossRef]

29. Eisenberg, S.W.F.; Ravesloot, L.; Koets, A.P.; Grünberg, W. Influence of Feeding a Low-Phosphorus Diet on Leucocyte Function in Dairy Cows. J. Dairy Sci. 2014, 97, 5176-5184. [CrossRef]

30. Mullarky, I.K.; Wark, W.A.; Dickenson, M.; Martin, S.; Petersson-Wolfe, C.S.; Knowlton, K.F. Short Communication: Analysis of Immune Function in Lactating Dairy Cows Fed Diets Varying in Phosphorus Content. J. Dairy Sci. 2009, 92, 365-368. [CrossRef]

31. Kiersztejn, M.; Chevru, I.; Smogorzewski, M.; Fadda, G.; Alexiewicz, J.; Massry, S. On the mechanisms of impaired phagocytotosis in phosphate depletion. J. Am. Soc. Nephrol. 1991, 2, 1484-1489. [CrossRef] 
32. Gröber, U.; Schmidt, J.; Kisters, K. Magnesium in Prevention and Therapy. Nutrients 2015, 7, 8199-8226. [CrossRef]

33. Martens, H.; Stumpff, F. Assessment of Magnesium Intake According to Requirement in Dairy Cows. J. Anim. Physiol. Anim. Nutr. 2019, 103, 1023-1029. [CrossRef]

34. Weglicki, W.B.; Phillips, T.M. Pathobiology of Magnesium Deficiency: A Cytokine/Neurogenic Inflammation Hypothesis. Am. J. Physiol. Regul. Integr. Comp. Physiol. 1992, 263, R734-R737. [CrossRef] [PubMed]

35. Malpuech-Brugere, C.; Nowacki, W.; Daveau, M.; Gueux, E.; Linard, C.; Rock, E.; Lebreton, J.; Mazur, A.; Rayssiguier, Y. Inflammatory response following acute magnesium deficiency in the rat. Biochim. Biophys. Acta 2000, 1501, 91-98. [CrossRef]

36. Van Orden, R.; Eggett, D.; Franz, K. Influence of Graded Magnesium Deficiencies on White Blood Cell Counts and Lymphocyte Subpopulations in rats. Magnes. Res. 2006, 19, 93-101.

37. Bussiere, F.; Gueux, E.; Rock, E.; Girardeau, J.; Tridon, A.; Mazur, A.; Rayssiguier, Y. Increased Phagocytosis And Production Of Reactive Oxygen Species By Neutrophils During Magnesium Deficiency in Rats And Inhibition by High Magnesium Concentration. Br. J. Nutr. 2002, 87, 107-113. [CrossRef]

38. Jelinski, M.; Waldner, C.; Penner, G. Case-Control Study of Mineral Concentrations of Hoof Horn Tissue Derived from Feedlot Cattle with Toe Tip Necrosis Syndrome (Toe Necrosis). Can. Vet. J. 2018, $59,7$.

39. An, L.; Marjani, S.L.; Wang, Z.; Liu, Z.; Liu, R.; Xue, F.; Xu, J.; Nedambale, T.L.; Yang, L.; Tian, X.C.; et al. Magnesium Is a Critical Element for Competent Development of Bovine Embryos. Theriogenology 2019, 140, 109-116. [CrossRef] [PubMed]

40. Ullah, H.; Khan, R.U.; Tufarelli, V.; Laudadio, V. Selenium: An Essential Micronutrient for Sustainable Dairy Cows Production Sustainability 2020, 12, 693. [CrossRef]

41. Machado, V.S.; Oikonomou, G.; Lima, S.F.; Bicalho, M.L.S.; Kacar, C.; Foditsch, C.; Felippe, M.J.; Gilbert, R.O.; Bicalho, R.C. The Effect of Injectable Trace Minerals (Selenium, Copper, Zinc, and Manganese) on Peripheral Blood Leukocyte Activity and Serum Superoxide Dismutase Activity of Lactating Holstein Cows. Vet. J. 2014, 200, 299-304. [CrossRef]

42. Hogan, J.S.; Smith, K.L.; Weiss, W.P.; Todhunter, D.A.; Schockey, W.L. Relationships Among Vitamin E, Selenium, and Bovine Blood Neutrophils. J. Dairy Sci. 1990, 73, 2372-2378. [CrossRef]

43. Jing, H.; Chen, Y.; Liang, W.; Chen, M.; Qiu, C.; Guo, M. Effects of Selenium on MAC-T Cells in Bovine Mastitis: Transcriptome Analysis of Exosomal MRNA Interactions. Biol. Trace Elem. Res. 2020, 199(8), 2904-2912. [CrossRef] [PubMed]

44. Wang, H.; Bi, C.; Wang, Y.; Sun, J.; Meng, X.; Li, J. Selenium Ameliorates Staphylococcus Aureus-Induced Inflammation in Bovine Mammary Epithelial Cells by Inhibiting Activation of TLR2, NF-KB and MAPK Signaling Pathways. BMC Vet. Res. 2018, 14, 197. [CrossRef] [PubMed]

45. Boyne, R.; Arthur, J.R. Effects of Selenium and Copper Deficiency on Neutrophil Function in Cattle. J. Comp. Pathol. 1981, 91, 271-276. [CrossRef]

46. Sripad, K.; Upendra, H.; Yathiray, S. Efficacy of Organic and Inorganic Selenium in Treatment of Bovine Subclinical Mastitis. IOSR J. Agric. Vet. Sci. 2016, 9, 31-35.

47. Hoque, M.N.; Das, Z.C.; Rahman, A.N.M.A.; Hoque, M.M. Effect of Administration of Vitamin E, Selenium and Antimicrobial Therapy on Incidence of Mastitis, Productive and Reproductive Performances in Dairy Cows. Int. J. Vet. Sci. Med. 2016, 4, 63-70. [CrossRef]

48. Zigo, F.; Farkasóvá, Z.; Eleko, J.; Lapin, M.; Chripková, M.; Czerski, A. Effect of Parenteral Administration of Selenium and Vitamin E on Health Status of Mammary Gland and on Selected Antioxidant Indexes in Blood of Dairy Cows. Pol. J. Vet. Sci. 2014, 17, 217-223. [CrossRef] [PubMed]

49. Smith, K.L.; Harrison, J.H.; Hancock, D.D.; Todhunter, D.A.; Conrad, H.R. Effect of Vitamin E and Selenium Supplementation on Incidence of Clinical Mastitis and Duration of Clinical Symptoms. J. Dairy Sci. 1984, 67, 1293-1300. [CrossRef]

50. Wang, D.; Jia, D.; He, R.; Lian, S.; Wang, J.; Wu, R. Association Between Serum Selenium Level and Subclinical Mastitis in Dairy Cattle. Biol. Trace Elem. Res. 2021, 199, 1389-1396. [CrossRef]

51. Muhee, A.; Malik, H.U.; Asharaf, I.; Shah, O.S.; Muheet, A.J.; Rather, W.; Muzamil, S. Therapeutic Efficacies of Self-Formulated Anti-Oxidant Trace Minerals Formulation in Bovine Mastitis. Int. J. Curr. Microbiol. App. Sci. 2017, 6, 4595-4599.

52. Żarczyńska, K.; Sobiech, P.; Mee, J.; Illek, J. The influence of short-term selenitetriglycerides supplementation on blood selenium, and hepatic, renal, metabolic and hematological parameters in dairy cows. Pol. J. Vet. Sci. 2020, 23, 637-646.

53. Pieszka, M.; Bederska-Łojewska, D.; Szczurek, P.; Pieszka, M. The Membrane Interactions of Nano-Silica and Its Potential Application in Animal Nutrition. Animals 2019, 9, 1041. [CrossRef]

54. Gopi, M.; Pearlin, B.; Kumar, R.D.; Shanmathy, M.; Prabakar, G. Role of Nanoparticles in Animal and Poultry Nutrition: Modes of Action and Applications in Formulating Feed Additives and Food Processing. Int. J. Pharmacol. 2017, 13, 724-731. [CrossRef]

55. Wichtel, J.J.; Keefe, G.P.; Leeuwen, J.A.V.; Spangler, E.; McNiven, M.A.; Ogilvie, T.H. The Selenium Status of Dairy Herds in Prince Edward Island. Can. Vet. J. 2004, 45,9.

56. Olivares, R.W.I.; Postma, G.C.; Schapira, A.; Iglesias, D.E.; Valdez, L.B.; Breininger, E.; Gazzaneo, P.D.; Minatel, L. Biochemical and Morphological Alterations in Hearts of Copper-Deficient Bovines. Biol. Trace Elem. Res. 2019, 189, 447-455. [CrossRef] [PubMed]

57. Suttle, F.N. Minerals in Animal Nutrition, 4th ed.; CABI: Oxfordshire, UK, 2010.

58. Reyes-Jara, A.; Cordero, N.; Aguirre, J.; Troncoso, M.; Figueroa, G. Antibacterial Effect of Copper on Microorganisms Isolated from Bovine Mastitis. Front. Microbiol. 2016, 7, 626. [CrossRef]

59. Wernicki, A.; Puchalski, A.; Urban-Chmiel, R.; Dec, M. Antimicrobial Properties of Gold, Silver, Copper and Platinum Nanoparticles against Selected Microorganisms Isolated from Cases of Mastitis in Cattle. Med. Weter. 2014, 70(9), $564-567$. 
60. Kalińska, A.; Jaworski, S.; Wierzbicki, M.; Gołębiewski, M. Silver and Copper Nanoparticles-An Alternative in Future Mastitis Treatment and Prevention? IJMS 2019, 20, 1672. [CrossRef] [PubMed]

61. Scaletti, R.W.; Trammell, D.S.; Smith, B.A.; Harmon, R.J. Role of Dietary Copper in Enhancing Resistance to Escherichia Coli Mastitis. J. Dairy Sci. 2003, 86, 1240-1249. [CrossRef]

62. Gakhar, G.; Randhawa, S.S.; Randhawa, C.S.; Bansal, B.K.; Singh, R.S. Effect of Copper on the Milk Quality and Prevention of Mastitis in Dairy Cows. Indian J. Anim. Sci. 2010, 80, 727-728.

63. Babu, U.; Failla, M.L. Respiratory Burst and Candidacidal Activity of Peritoneal Macrophages Are Impaired in Copper-Deficient Rats. J. Nutr. 1990, 120, 1692-1699. [CrossRef]

64. Willing, B.P.; Pepin, D.M.; Marcolla, C.S.; Forgie, A.J.; Diether, N.E.; Bourrie, B.C.T. Bacterial Resistance to Antibiotic Alternatives: A Wolf in Sheep's Clothing? Anim. Front. 2018, 8, 39-47. [CrossRef]

65. Anchordoquy, J.M.; Anchordoquy, J.P.; Galarza, E.M.; Farnetano, N.A.; Giuliodori, M.J.; Nikoloff, N.; Fazzio, L.E.; Furnus, C.C. Parenteral Zinc Supplementation Increases Pregnancy Rates in Beef Cows. Biol. Trace Elem. Res. 2019, 192, 175-182. [CrossRef] [PubMed]

66. Cope, C.M.; Mackenzie, A.M.; Wilde, D.; Sinclair, L.A. Effects of Level and Form of Dietary Zinc on Dairy Cow Performance and Health. J. Dairy Sci. 2009, 92, 2128-2135. [CrossRef] [PubMed]

67. Chandra, G.; Aggarwal, A.; Singh, A.K.; Kumar, M. Effect of Vitamin E and Zinc Supplementation on Milk Yield, Milk Composition, and Udder Health in Sahiwal Cows. Anim. Nutr. Feed Tech. 2015, 15, 67. [CrossRef]

68. Whitaker, D.A.; Eares, H.F.; Ait, K.; Kelly, J.M. No Effect of a Dietary Zinc Proteinate on Clinical Mastiffs, Infection Rate, Recovery Rate and Somatic Cell Count in Dairy Cows. Vet. J. 1997, 153, 197-204. [CrossRef]

69. Weng, X.; Monteiro, A.P.A.; Guo, J.; Li, C.; Orellana, R.M.; Marins, T.N.; Bernard, J.K.; Tomlinson, D.J.; DeFrain, J.M.; Wohlgemuth, S.E.; et al. Effects of Heat Stress and Dietary Zinc Source on Performance and Mammary Epithelial Integrity of Lactating Dairy Cows. J. Dairy Sci. 2018, 101, 2617-2630. [CrossRef] [PubMed]

70. Shaffer, J.; Pandalaneni, K.; Mamedova, L.; DeFrain, J.; Amamcharla, J.; Bradford, B. Effects of Dietary Zinc Source and Level on Mammary Epithelia and Dairy Food Chemistry. Kans. Agric. Exp. Stn. Res. Rep. 2016, 2, 8. [CrossRef]

71. Prasad, A.S. Discovery of Human Zinc Deficiency: Its Impact on Human Health and Disease. Adv. Nutr. 2013, 4, 176-190 [CrossRef]

72. Hill, E.K.; Li, J. Current and Future Prospects for Nanotechnology in Animal Production. J. Anim. Sci. Biotechnol. 2017, 8, 26. [CrossRef]

73. Rai, M.K.; Deshmukh, S.D.; Ingle, A.P.; Gade, A.K. Silver Nanoparticles: The Powerful Nanoweapon against Multidrug-Resistant Bacteria: Activity of Silver Nanoparticles against MDR Bacteria. J. Appl. Microbiol. 2012, 112, 841-852. [CrossRef]

74. Li, Y.; Zhang, W.; Niu, J.; Chen, Y. Mechanism of Photogenerated Reactive Oxygen Species and Correlation with the Antibacterial Properties of Engineered Metal-Oxide Nanoparticles. ACS Nano 2012, 6, 5164-5173. [CrossRef]

75. Kruk, T.; Szczepanowicz, K.; Stefańska, J.; Socha, R.P.; Warszyński, P. Synthesis and Antimicrobial Activity of Monodisperse Copper Nanoparticles. Colloids Surf. Biointerfaces 2015, 128, 17-22. [CrossRef] [PubMed]

76. Elbehiry, A.; Al-Dubaib, M.; Marzouk, E.; Moussa, I. Antibacterial Effects and Resistance Induction of Silver and Gold Nanoparticles against Staphylococcus Aureus-induced Mastitis and the Potential Toxicity in Rats. MicrobiologyOpen 2019, 8, e00698. [CrossRef] [PubMed]

77. Hozyen, H.F.; Ibrahim, E.S.; Khairy, E.A.; El-Dek, S.I. Enhanced Antibacterial Activity of Capped Zinc Oxide Nanoparticles: A Step towards the Control of Clinical Bovine Mastitis. Vet. World 2019, 12, 1225-1232. [CrossRef]

78. Jagielski, T.; Bakuła, Z.; Pleń, M.; Kamiński, M.; Nowakowska, J.; Bielecki, J.; Wolska, K.I.; Grudniak, A.M. The Activity of Silver Nanoparticles against Microalgae of the Prototheca Genus. Nanomedicine 2018, 13, 1025-1036. [CrossRef] [PubMed]

79. Castiglioni, S. Short- and Long-Term Effects of Silver Nanoparticles on Human Microvascular Endothelial Cells. WJBC 2014, 5, 457. [CrossRef] [PubMed]

80. Oliveira, L.; Ruegg, P.L. Treatments of Clinical Mastitis Occurring in Cows on 51 Large Dairy Herds in Wisconsin. J. Dairy Sci. 2014, 97, 5426-5436. [CrossRef] [PubMed]

81. Ferreira, G.M.; Petzer, I.-M. Injectable Organic and Inorganic Selenium in Dairy Cows-Effects on Milk, Blood and Somatic Cell Count Levels. Onderstepoort J. Vet. Res. 2019, 86, a1664. [CrossRef]

82. Bourne, N.; Wathes, D.C.; Lawrence, K.E.; McGowan, M.; Laven, R.A. The Effect of Parenteral Supplementation of Vitamin E with Selenium on the Health and Productivity of Dairy Cattle in the UK. Vet. J. 2008, 177, 381-387. [CrossRef]

83. Smulski, S.; Gehrke, M.; Libera, K.; Cieślak, A.; Huang, H.; Patra, A.K.; Szumacher-Strabel, M. Effects of Various Mastitis Treatments on the Reproductive Performance of Cows. BMC Vet. Res. 2020, 16, 99. [CrossRef] 